\title{
Introducing Seriascoma yunnanense sp. nov. (Occultibambusaceae, Pleosporales) based on evidence from morphology and phylogeny
}

\author{
Rathnayaka $\mathrm{AR}^{1,2}$, Dayarathne $\mathrm{MC}^{1,2,3}$, Maharachchikumbura SSN ${ }^{4}$, Liu $\mathrm{JK}^{4}$, \\ Tennakoon $\mathrm{DS}^{1,2,3,5}$ and Hyde $\mathrm{KD}^{1,2,3}$
}

\author{
${ }^{1}$ Center of Excellence in Fungal Research, Mae Fah Luang University, Chiang Rai 57100, Thailand \\ ${ }^{2}$ School of Science, Mae Fah Luang University, Chiang Rai57100, Thailand \\ ${ }^{3}$ Key Laboratory for Plant Biodiversity and Biogeography of East Asia (KLPB), Kunming Institute of Botany, Chinese \\ Academy of Science, Kunming 650201, People's Republic of China \\ ${ }^{4}$ School of Life Science and Technology, University of Electronic Science and Technology of China, Chengdu, 611731, \\ People's Republic of China \\ ${ }^{5}$ Department of Plant Medicine, National Chiayi University, 300 Syuefu Road, Chiayi City 60004, Taiwan
}

Rathnayaka AR, Dayarathne MC, Maharachchikumbura SSN, Liu JK, Tennakoon DS, Hyde KD 2019 - Introducing Seriascoma yunnanense sp. nov. (Occultibambusaceae, Pleosporales) based on evidence from morphology and phylogeny. Asian Journal of Mycology 2(1), 245-253, Doi 10.5943/ajom/2/1/15

\begin{abstract}
In this study, we introduce a new fungal species from dead branches of bamboo (Poaceae) in Yunnan Province, China. Combined LSU, SSU, RPB2 and TEF1- $\alpha$ gene sequence data analysis showed it belongs to the family Occultibambusaceae (Pleosporales). Maximum likelihood and Bayesian analyses were performed to clarify the phylogenetic affinities of the taxon. The novel species is typical to Seriascoma in its elongated, gregarious, ostiolate ascostromata, immersed beneath the clypeus and clavate to fusiform, didymosporous, hyaline ascospores, but differs from $S$. didymospora in having uni-loculate ascostromata, short pedicellate asci and ascospores with gelatinous sheath and relatively large guttules. The new taxon is compared with known Seriascoma species and a comprehensive description and micrographs are provided.
\end{abstract}

Key words - 1 new taxon - Dothideomycetes - Multi-gene - Phylogenetic analysis - Taxonomy

\section{Introduction}

Occultibambusaceae D.Q. Dai \& K.D. Hyde was introduced by Dai et al. (2017) and is typified by Occultibambusa D.Q. Dai \& K.D. Hyde (with the type species O. bambusae D.Q. Dai \& K.D. Hyde). The family comprises the genera Neooccultibambusa Doilom \& K.D. Hyde, Occultibambusa, Seriascoma Phook., D.Q. Dai \& K.D. Hyde and Versicolorisporium Sat. Hatak., Kaz. Tanaka \& Y. Harada (Hatakeyama et al. 2008, Doilom et al. 2017, Wijayawardene et al. 2018). Members of Occultibambusaceae usually occur on the monocotyledons such as bamboo and have also been found on teak (Tectona grandis) (Dai et al. 2017, Doilom et al. 2017). Species of Occultibambusaceae have immersed, solitary to gregarious ascomata with black ostioles, bitunicate, broadly cylindrical to clavate asci, cellular pseudoparaphyses and broad-fusiform, hyaline to dark brown, 1-3 septate ascospores (Dai et al. 2017). The asci and ascospore characters of Occultibambusaceae are similar to some other members in Pleosporales, viz. Bambusicola D.Q. Dai \& K.D. Hyde (Bambusicolaceae), Lophiostoma Ces. \& De Not. (Lophiostomataceae) and 
Massarina Sacc., (Massarinaceae) (Zhang et al. 2009, Dai et al. 2012, 2015, Tibpromma et al. 2018). Asexual morphs of Occultibambusaceae are diverse in their morphology, which often comprises eustromatic conidiomata, phialidic conidiogenous cells with enteroblastic conidiogenesis (Dai et al. 2017).

The monotypic genus Seriascoma, typified by S. didymospora Phookamsak, D.Q. Dai \& K.D. Hyde was introduced by Dai et al. (2017) and found on bamboo (Dai et al. 2017). Seriascoma species are characterized by elongated, gregarious, coriaceous, multiloculate, ostiolate ascostromata, immersed beneath a clypeus, which are erumpent with a slit-like opening, a thick-walled peridium composed of dark brown cell layers of textura angularis and clavate to fusiform, didymosporous, hyaline ascospores arranged in bitunicate asci (Dai et al. 2017). Seriascoma can be distinguished from other genera in Occultibambusaceae by having ascostromata occurring under a clypeus (Dai et al. 2017). The asexual morphs of Seriascoma comprise solitary to gregarious, conical, uniloculate, black, eustromatic conidiomata (Dai et al. 2017). The conidiomatal wall consists of pseudoparenchymatous cells, arranged in a textura angularis and produce oblong, aseptate, hyaline conidia (Dai et al. 2017).

The purpose of this study is to introduce a novel taxon, Seriascoma yunnanense, which was collected from Yunnan Province, China. Morphological comparison and Maximum likelihood (ML), Bayesian inference (BI) analyses of combined LSU, SSU, RBP2 and TEF1- $\alpha$ sequence data confirmed the phylogenetic placement of the novel species within the family Occultibambusaceae.

\section{Materials \& Methods}

\section{Sample collection and morphological studies}

Dead branches of bamboo samples were collected from Yunnan Province, China on 24 May 2018 and brought to the laboratory in Zip lock plastic bags. Slides were prepared by handsectioning of ascostromata and examined using the Motic SMZ-171 stereomicroscope. Indian ink was used to observe the gelatinous sheath of the ascospores. Morphological characters were observed using Nikon Eclipse 80i compound microscope and photomicrography recorded with a Canon 600D digital camera fitted to the microscope. Measurements of morphological characters were taken using Tarosoft (R) Image Frame Work version 0.9.7. Adobe Photoshop CS3 Extended version 10.0 was used to prepare the photo plates. The herbarium material was deposited in the Mae Fah Luang University Herbarium (MFLU), Chiang Rai, Thailand and the Herbarium of Kunming Institute of Botany (HKAS), China. Faces of fungi number was obtained as explained in Jayasiri et al. (2015) and Index Fungorum number was registered in Index Fungorum (2019).

\section{DNA extraction, PCR amplification and sequencing}

Genomic DNA was directly extracted from the ascostromata using a DNA extraction kit (E.Z.N.A. ${ }^{\circledR}$ Forensic DNA kit, D3591-01, Omega Bio-Tek) following the manufacturer's instructions. Large subunit rDNA (LSU), Small subunit rDNA (SSU), RNA polymerase II second largest subunit gene (RPB2) and Translation elongation factor 1- $\alpha$ gene (TEF1- $\alpha$ ) gene were amplified with LR0R/LR5 (Vilgalys \& Hester 1990, Rehner \& Samuels 1994), NS1/NS4 (White et al. 1990), RPB2-5f/fRPB2-7cr (Liu et al. 1999, Sung et al. 2007) and EF1-983F/EF1-1567R (Rehner 2001, Rehner \& Buckley 2005) primers in respectively. PCR amplification reactions were done using the following PCR components. The final volume of the PCR mixture was $25 \mu 1$

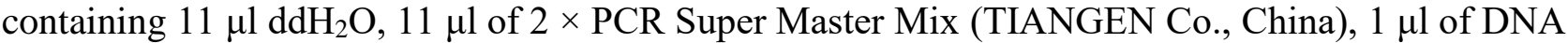
template, $1 \mu \mathrm{l}$ of each forward and reverse primers $(10 \mu \mathrm{l})$. The temperature profile for the amplification of LSU, SSU and TEF1- $\alpha$ gene regions were performed with initially denaturing step at $94{ }^{\circ} \mathrm{C}$ for $3 \mathrm{~min}$, followed by 35 amplification cycles of denaturation at $94{ }^{\circ} \mathrm{C}$ for $30 \mathrm{~s}$, annealing at $55{ }^{\circ} \mathrm{C}$ for $50 \mathrm{~s}$, extension at $72{ }^{\circ} \mathrm{C}$ for $1 \mathrm{~min}$ and final extension step of $72{ }^{\circ} \mathrm{C}$ for $10 \mathrm{~min}$. Thermal cycle for $R B P 2$ gene amplification was initially denaturing at $95^{\circ} \mathrm{C}$ for $5 \mathrm{~min}$, followed by 35 cycles of denaturation at $95{ }^{\circ} \mathrm{C}$ for $1 \mathrm{~min}$, annealing at $52{ }^{\circ} \mathrm{C}$ for $2 \mathrm{~min}$, extension at $72{ }^{\circ} \mathrm{C}$ for $90 \mathrm{~s}$ and final extension step of $72{ }^{\circ} \mathrm{C}$ for $10 \mathrm{~min}$. The PCR products were observed on $2 \%$ agarose 
electrophoresis gels stained with ethidium bromide. Purification and DNA sequencing were performed at Sunbiotech Company, Beijing, China.

\section{Phylogenetic analysis}

Sequences generated from reverse and forward primers were combined using SeqMan software version: 7.1.0 (44.1). Sequences of the family Occultibambusaceae were obtained from the GenBank following recent publications and literature (Dai et al. 2017, Zhang et al. 2017). Sequencing data were initially aligned using MAFFT v. 6.864b software (http://mafft.cbrc.jp/alignment/server/index.html). The single-gene alignment of each region was refined manually with Bioedit 7 v. 7.0.9.0 (Hall 1999) and improved using Trimmal (Phylemon 2.0) (http://phylemon.bioinfo.cipf.es/alignment.html). Phylogenetic analysis was carried out using ML and BI analyses. ML trees for each single gene region and combined gene regions were generated using the RAxML-HPC2 on XSEDE (v. 8.2.10) (Stamatakis 2014) in the CIPRES Science Gateway platform (Miller et al. 2010). In this analysis nonparametric bootstrap iterations (Stamatakis et al. 2008) was run in 1,000 replicates with the GTR model and discrete gamma distribution (Liu et al. 2011).

MrBayes v.3.0b4 (Ronquist \& Huelsenbeck 2003) was used to perform the BI for each single gene region and combined gene data sets. Best-fit models for BI and ML analyses were selected using MrModeltest v. 2.2 (Nylander 2004). For all four data sets, a dirichlet state frequency was predicted and the GTR $+\mathrm{I}+\mathrm{G}$ model was selected as the best model. The heating parameter was set to 0.2 and trees were saved every 1,000 generations (Ronquist et al. 2012). Posterior probabilities (PP) (Rannala et al. 1998, Zhaxybayeva \& Gogarten 2002) were determined by Markov Chain Monte Carlo sampling in MrBayes v. 3.0b4 (Huelsenbeck \& Ronquist 2001). Six simultaneous Markov Chain Monte Carlo chains were run for 1,000,000 generations and trees were sampled every $1000^{\text {th }}$ generation resulting in 1000 total trees. The first 100 trees were represented the burnin-phase of the analysis and they were discarded and 900 trees were used to calculate PP in the majority rule consensus tree. The resulting phylogenetic trees were visualized in FigTree v.1.4.0 (Rambaut 2012) and with Microsoft PowerPoint (2016).

Table 1 Taxa used in the phylogenetic analysis and their GenBank accession numbers. New taxon generated in this study is in blue and type strains are in bold.

\begin{tabular}{|c|c|c|c|c|c|}
\hline \multirow[t]{2}{*}{ Species name } & \multirow[t]{2}{*}{ Strain No } & \multicolumn{4}{|c|}{ GenBank accessions } \\
\hline & & LSU & SSU & RPB2 & TEF1- $\alpha$ \\
\hline Biatriospora mackinnonii & CBS 674.75 & KF015612 & GQ387552 & KF015703 & KF407986 \\
\hline B. marina & CY 1228 & GQ925848 & GQ925835 & GU479823 & GU479848 \\
\hline B. peruviensis & CCF4485 & LN626683 & LN626677 & LN626665 & LN626671 \\
\hline Neooccultibambusa chiangraiensis & MFLUCC 12-0559 & - & NG061230 & - & - \\
\hline$N$. jonesii & MFLUCC 16-0643 & NG059741 & NG062422 & - & - \\
\hline N. pandanicola & KMUCC 17-0179 & MG298940 & MG298942 & MG298944 & MG298943 \\
\hline N. thailandensis & $\begin{array}{l}\text { MFLUCC } \\
16-0274\end{array}$ & MH260308 & MH260348 & MH412758 & MH412780 \\
\hline Neoroussoella bambusae & $\begin{array}{l}\text { MFLUCC } \\
11-0124\end{array}$ & KJ474839 & - & KJ474856 & KJ474848 \\
\hline Occultibambusa aquatica & $\begin{array}{l}\text { MFLUCC } \\
11-0006\end{array}$ & KX698110 & KX698112 & - & - \\
\hline O. bambusae & $\begin{array}{l}\text { MFLUCC } \\
11-0394\end{array}$ & KU863113 & - & KU940171 & KU940194 \\
\hline O. bambusae & $\begin{array}{l}\text { MFLU } \\
15-1212\end{array}$ & - & NG061237 & - & - \\
\hline O. bambusae & $\begin{array}{l}\text { MFLUCC } \\
13-0855\end{array}$ & KU863112 & - & KU940170 & KU940193 \\
\hline
\end{tabular}


Table 1 Continued.

\begin{tabular}{|c|c|c|c|c|c|}
\hline \multirow[t]{2}{*}{ Species name } & \multirow[t]{2}{*}{ Strain No } & \multicolumn{4}{|c|}{ GenBank accessions } \\
\hline & & LSU & SSU & RPB2 & TEF1- $\alpha$ \\
\hline O. bambusae & $\begin{array}{l}\text { MFLU } \\
16-0880\end{array}$ & - & KU872117 & - & - \\
\hline O. chiangraiensis & $\begin{array}{l}\text { MFLUCC } \\
16-0380\end{array}$ & KX655546 & NG062421 & KX655566 & KX655561 \\
\hline O. fusispora & $\begin{array}{l}\text { MFLUCC } \\
11-0127\end{array}$ & NG059669 & - & KU940172 & KU940195 \\
\hline O. jonesii & $\begin{array}{l}\text { GZCC } \\
16-0117\end{array}$ & KY628322 & KY628324 & KY814758 & KY814756 \\
\hline O. maolanensis & $\begin{array}{l}\text { GZCC } \\
16-0116\end{array}$ & KY628323 & KY628325 & KY814759 & KY814757 \\
\hline O. pustula & $\begin{array}{l}\text { MFLU } \\
15-1185\end{array}$ & - & NG062419 & - & - \\
\hline O. pustula & $\begin{array}{l}\text { MFLUCC } \\
11-0502\end{array}$ & KU863115 & - & - & - \\
\hline Paradictyoarthrinium diffractum & $\begin{array}{l}\text { MFLUCC } \\
13-0466\end{array}$ & KP744498 & KP753960 & KX437764 & - \\
\hline P. tectonicola & $\begin{array}{l}\text { MFLUCC } \\
13-0465\end{array}$ & NG059558 & KP753961 & KX437763 & - \\
\hline Roussoella hysterioides & HH 26988 & AB524622 & AB524481 & AB539102 & AB539115 \\
\hline R. nitidula & MFLUCC 11-0634 & KJ474842 & - & KJ474858 & KJ474851 \\
\hline R. nitidula & $\begin{array}{l}\text { MFLUCC } \\
11-0182\end{array}$ & KJ474843 & - & KJ474859 & KJ474852 \\
\hline R. pustulans & KT 1709 & AB524623 & AB524482 & AB539103 & AB539116 \\
\hline Seriascoma didymospora & $\begin{array}{l}\text { MFLUCC } \\
11-0179\end{array}$ & NG059670 & - & KU940173 & KU940196 \\
\hline S. didymospora & $\begin{array}{l}\text { MFLUCC } \\
11-0194\end{array}$ & KU863117 & - & KU940174 & KU940197 \\
\hline S. yunnanense & MFLU 19-0690 & MN174695 & MN174694 & MN210324 & IF556782 \\
\hline Torula herbarum & CBS 379.58 & KF443383 & KF443388 & GU456362 & KF443400 \\
\hline T. herbarum & CBS 111855 & KF443386 & KF443391 & KF443396 & KF443403 \\
\hline T. pluriseptata & $\begin{array}{l}\text { MFLUCC } \\
14-0437\end{array}$ & KY197855 & KY197862 & KY197869 & KY197875 \\
\hline Westerdykella ornata & CBS 379.55 & NG057861 & NG061101 & GU371803 & GU349021 \\
\hline
\end{tabular}

\section{Results}

\section{Phylogenetic analyses}

The combined LSU, SSU, RPB2 and TEF1- $\alpha$ data set comprises 32 taxa with Paradictyoarthrinium diffractum (MFLUCC 13-0466), P. tectonicola (MFLUCC 13-0465) and Westerdykella ornata (CBS 379.55) as the outgroup taxa. The dataset comprises 3,781 characters (LSU: 874, SSU: 992, RBP2: 1027, TEF1- $\alpha$ : 888) after alignments, including gaps. Seventeen sequences of Occultibambusaceae were obtained from GenBank, which represent three genera in this family. Single gene analyses were performed and each tree has similar topology. Tree topologies of the ML and BI analyses were similar to each other. The best RAxML tree with a final likelihood value of -18435.756238 is presented (Fig. 1). The matrix had 1135 distinct alignment patterns, with $27.98 \%$ undetermined characters or gaps. Estimated base frequencies were as follows: $\mathrm{A}=0.250266, \mathrm{C}=0.247992, \mathrm{G}=0.270472, \mathrm{~T}=0.231270$; substitution rates $\mathrm{AC}=$ 1.372546, $\mathrm{AG}=4.220271, \mathrm{AT}=1.312711, \mathrm{CG}=1.127677, \mathrm{CT}=8.919304, \mathrm{GT}=1.000000$; gamma distribution shape parameter $\alpha=0.151881$. According to the results of BI, the average standard deviation of split frequencies was 0.0108. The new species Seriascoma yunnanense (MFLU 19-0690) formed a well separated (99\% ML, 0.95 PP) clade to S. didymospora (MFLUCC 11-0179 and MFLUCC 11-0194) within the genus Seriascoma. 


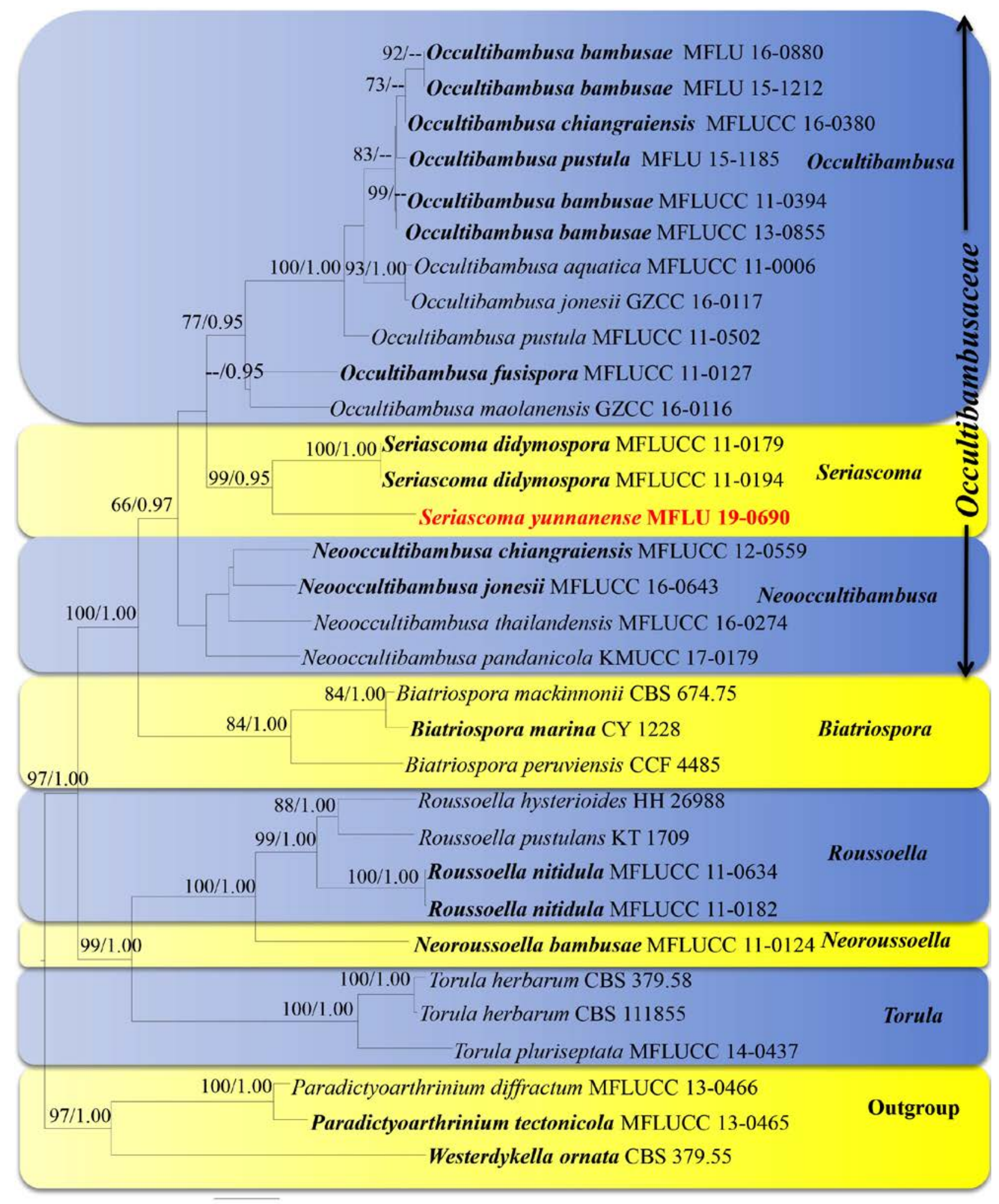

0.03

Fig. 1 - Phylogram generated from ML analysis based on combined LSU, SSU, RBP2 and TEF1- $\alpha$ sequence data. ML values $\geq 65 \%$ and Bayesian posterior probabilities $(\mathrm{PP}) \geq 0.95$ are mentioned at the nodes. The newly generated sequence is in red bold and the type strains are in bold. The isolates numbers are noted after the species names. The tree is rooted to Paradictyoarthrinium diffractum (MFLUCC 13-0466), P. tectonicola (MFLUCC 13-0465) and Westerdykella ornata (CBS 379.55). 


\section{Taxonomy}

Seriascoma yunnanense Rathnayaka \& K.D. Hyde, sp. nov.

Fig. 2

Index Fungorum number: IF556782; Facesoffungi number: FoF 01681

Etymology - In reference to the Yunnan Province, China where the fungus was collected

Holotype - MFLU 19-0690

Saprobic on dead branches of bamboo. Sexual morph: Ascostromata 175-205 $\mu \mathrm{m}$ high, 275$400 \mu \mathrm{m}$ diam., solitary or gregarious, immersed beneath clypeus, coriaceous, raised, erumpent in host, with a central ostiole uni-loculate, dark brown to black, globose to subglobose, papillate. Peridium 26-63.7 $\mu \mathrm{m}$ wide, thin- to thick-walled, sometimes unequal in thickness, thicker at the sides towards apex, thinner at the base, composed of several layers of small, brown to dark brown cells of textura angularis. Hamathecium 1.4-2.8 $\mu \mathrm{m}$ wide, comprising numerous, branched, cellular pseudoparaphyses. Asci 44-83 × 10-20 $\mu \mathrm{m}(\overline{\mathrm{x}}=62 \times 14 \mu \mathrm{m}, \mathrm{n}=30), 8$-spored, bitunicate, fissitunicate, clavate, short pedicellate, with furcate ends, apically rounded, with well-developed ocular chamber. Ascospores 22-30 $\times 5-7.2 \mu \mathrm{m}(\overline{\mathrm{x}}=24.4 \times 6.5 \mu \mathrm{m}, \mathrm{n}=30)$, overlapping, uni- to triseriate, didymosporous, slightly broad and fusiform, with rounded ends, hyaline, slightly constricted at the septum, straight to curved, with upper cell larger than lower cell, smooth-walled, surrounded by a gelatinous sheath, with guttules. Asexual morph: Undetermined.

Material examined - CHINA, Yunnan Province, on dead branches of bamboo, 24 May 2018, H. Ekanayaka (MFLU 19-0690, holotype), (HKAS102114, isotype).

Notes - The morphological characters of Seriascoma yunnanense fit with the generic concept of Seriascoma in having ascostromata that are immersed beneath a clypeus and didymosporous ascospores (Dai et al. 2017). The sexual morph of $S$. yunnanense is morphologically similar to $S$. didymospora but distinctly differs from ascostromatal characters. The ascostromata of $S$. didymospora are erumpent in linear rows and multi-loculate with slit-like openings (Dai et al. 2017), whereas S. yunnanense has scattered and uni-loculate ascostromata. Seriascoma didymospora also has larger ascostromata (1000-1900 $\mu \mathrm{m})$ than those in S. yunnanense (275-400 $\mu \mathrm{m})$ (Dai et al. 2017). In addition, $S$. yunnanense has larger ascospores $(\overline{\mathrm{x}}=24.4 \times 6.5 \mu \mathrm{m})$ with a gelatinous sheath and larger guttules, but $S$. didymospora has smaller ascospores $(\overline{\mathrm{x}}=11.9 \times 3.9$ $\mu \mathrm{m})$ with comparatively smaller guttules and lacks a gelatinous sheath (Dai et al. 2017). A multigene phylogeny generated herein (Fig. 1) indicates that these species are phylogenetically distinct and $S$. yunnanense can be recognized as a new species.

\section{Discussion}

More than 1300 fungal species are recorded on bamboo and microfungi are abundant in culms and leaves (Dai et al. 2018). Ascomycetes are the most abundant species in bamboo, with around 1150 taxa recorded (Dai et al. 2018).

Seriascoma is a relatively poorly known genus and comprises only the type species, $S$. didymospora. In this study, we provide taxonomic details for another new species; $S$. yunnanense collected from dead branches of bamboo and expands the genus to include two species. According to the phylogenetic investigations, $S$. yunnanense clusters with $S$. didymospora with high bootstrap support (99\% ML, and $0.95 \mathrm{PP}$ ). In the comparison of the LSU, RBP2 and TEF1- $\alpha$ DNA sequence data between $S$. yunnanense and $S$. didymospora also revealed $2.3 \%, 15 \%$ and $7 \%$ nucleotide differences respectively that supports our establishment of the new taxon as the guidelines of Jeewon \& Hyde (2016).

Seriascoma formed a robust clade close to genus Neooccultibambusa in our phylogenetic analysis which is similar to the study by Doilom et al. (2017). Seriascoma and Neooccultibambusa share similar characteristics, with both genera having uniloculate, globose to subglobose ascostromata and ascospores with gelatinous sheaths and large guttules (Doilom et al. 2017). However, these genera are distinguished by ascospore morphology. 


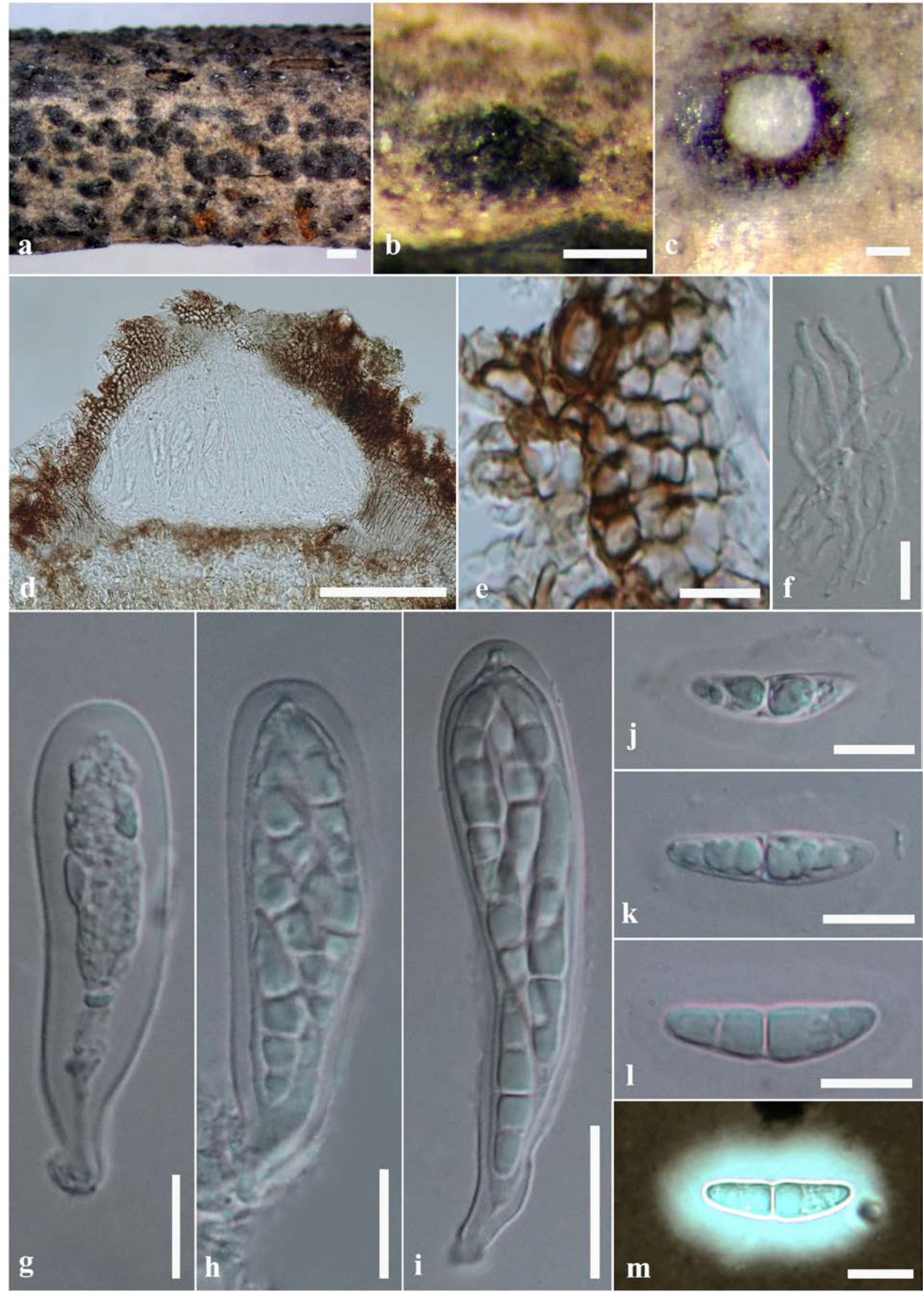

Fig. 2 - Seriascoma yunnanense (MFLU 19-0690, holotype). a, b Appearance of ascostromata on host surface. c Transverse section of ascostroma. d Vertical section through locule of ascostroma. e Section through peridium. f Pseudoparaphyses. g-i Immature to mature asci. j-l Immature to mature ascospores. $\mathrm{m}$ Ascospore showing gelatinous sheath stained with Indian ink. Scale bars: $\mathrm{a}=$ $500 \mu \mathrm{m}, \mathrm{b}=200 \mu \mathrm{m}, \mathrm{c}=100 \mu \mathrm{m}, \mathrm{d}=100 \mu \mathrm{m}, \mathrm{e}-\mathrm{h}, \mathrm{j}-\mathrm{m}=10 \mu \mathrm{m}, \mathrm{i}=20 \mu \mathrm{m}$. 
The ascospores of Neooccultibambusa are initially hyaline and become pale brown when mature (Doilom et al. 2017). However, the ascospores of Seriascoma are hyaline when mature (Dai et al. 2017). Seriascoma and Occultibambusa also share somewhat similar morphological characters and both genera have asci with short furcate pedicels and guttulate ascospores with larger upper cells and surrounded by a gelatinous sheath (Dai et al. 2017). However, the genus Occultibambusa has dark brown ascospores (Dai et al. 2017), while S. yunnanense has hyaline ascospores.

Versicolorisporium, which belongs to family Occultibambusaceae, was excluded in our phylogenetic analysis. Because the phylogenetic placement of Versicolorisporium is not wellresolved (Zhang et al. 2017).

\section{Acknowledgments}

Achala Rathnayaka offers her deepest gratitude to Hasini Ekanayaka for collecting the specimens and sequencing. K.D. Hyde thanks the Thailand Research Fund for a grant, number RDG6130001, entitled "Impact of climate change on fungal diversity and biogeography in the Greater Mekong Subregion grant number.

\section{References}

Dai DQ, Bhat DJ, Liu JK, Chukeatirote E et al. 2012 - Bambusicola, a new genus from bamboo with asexual and sexual morphs. Cryptogamie Mycologie 33, 363-379.

Dai DQ, Bahkali AH, Li WJ, Bhat DJ et al. 2015 - Bambusicola loculata sp. nov. (Bambusicolaceae) from bamboo. Phytotaxa 213, 122-130.

Dai DQ, Phookamsak R, Wijayawardene NN, Li WJ et al. 2017 - Bambusicolous fungi. Fungal Diversity 82, 1-105.

Dai DQ, Tang LZ, Wang HB. 2018 - A review of bambusicolous ascomycetes. In: Abdul Khalil HPS (eds) Bamboo - Current and future prospects. IntechOpen, pp 165-183.

Doilom M, Dissanayake AJ, Wanasinghe DN, Boonmee S et al. 2017 - Microfungi on Tectona grandis (teak) in Northern Thailand. Fungal Diversity 82, 107-182.

Hall TA. 1999 - BioEdit: a user-friendly biological sequence alignment editor and analysis program for Windows 95/98/NT. Nucleic Acids Symposium Series 41, 95-98.

Hatakeyama S, Tanaka K, Harada Y. 2008 - Bambusicolous fungi in Japan (7): a new coelomycetous genus, Versicolorisporium. Mycoscience 49, 211-214.

Huelsenbeck JP, Ronquist FR. 2001 - MrBayes: Bayesian inference of 380 phylogenetics trees. Biometrics 17, 754-755.

Index Fungorum. 2019 - http://www.indexfungorumorg/Names/ Namesasp (Accessed on January 2019).

Jayasiri SC, Hyde KD, Ariyawansa HA, Bhat J et al. 2015 - The Faces of Fungi database: fungal names linked with morphology, phylogeny and human impacts. Fungal Diversity 74, 3-18.

Jeewon R, Hyde KD. 2016 - Establishing species boundaries and new taxa among fungi: recommendations to resolve taxonomic ambiguities. Mycosphere 7, 1669-1677.

Liu JK, Phookamsak R, Jones EBG, Zhang Y et al. 2011 - Astrosphaeriella is polyphyletic, with species in Fissuroma gen. nov., and Neoastrosphaeriella gen. nov. Fungal Diversity 51, 135154.

Liu YJ, Whelen S, Hall BD. 1999 - Phylogenetic relationships among ascomycetes evidence from an RNA polymerase II subunit. Molecular Biology and Evolution 16, 1799-1808.

MAFFT v. 6.864b. 2019 - http://mafft.cbrc.jp/alignment/server/index.html, (Accessed 2 Feb 2019).

Miller MA, Pfeiffer W, Schwartz T. 2010 - Creating the CIPRES science gateway for inference of large phylogenetic trees. Proceedings of the Gateway Computing Environments Workshop (GCE) 1: 1-8. https://doi.org/10.1109/GCE.2010.5676129

Nylander JAA. 2004 - MrModeltest 2.0. Program distributed by the author. Evolutionary Biology Centre, Uppsala University.

Phylemon 2.0. 2019 - http://phylemon.bioinfo.cipf.es/alignment.html, (Accessed 3 Feb 2019) 
Rambaut A. 2012 - Fig.Tree. Tree Fig. Drawing Tool, v. 1.4.0. Available from: http://tree.bio.ed.ac.uk/software/figtree/, (Accessed 10 Feb 2019)

Rannala B, Huelsenbeck JP, Yang Z, Nielsen R. 1998 - Taxon sampling and the accuracy of large phylogenies. Systematic Biology 47, 702-710.

Rehner SA, Buckley E. 2005 - A Beauveria phylogeny inferred from nuclear ITS and EF1-a sequences: evidence for cryptic diversification and links to Cordyceps teleomorphs. Mycologia 97, 84-98.

Rehner S. 2001 - Primers for elongation factor 1- $\alpha$ (EF1- $\alpha$ ). http://www. aftol.org/pdfs/EF1primer.pdf (Accessed 2 Feb 2019)

Rehner SA, Samuels GJ. 1994 - Taxonomy and phylogeny of Gliocladium analysed from nuclear large subunit ribosomal DNA sequences. Mycological Research 98, 625-634.

Ronquist F, Huelsenbeck JP. 2003 - MrBayes 3: Bayesian phylogenetic inference under mixed models. Bioinformatics 19, 1572-1574.

Ronquist F, Teslenko M, van der Mark P. 2012 - MrBayes 3.2: efficient Bayesian phylogenetic inference and model choice across a large model space. Systematic Biology 61, 539-542.

Stamatakis A. 2014 - RAxML version 8: a tool for phylogenetic analysis and post-analysis of large phylogenies. Bioinformatics 30, 1312-1313.

Stamatakis A, Hoover P, Rougemont J. 2008 - A rapid bootstrap algorithmfor the RAxMLWeb Servers. Systematic Biology 57, 758-771.

Sung GH, Sung JM, Hywel-Jones NL, Spatafora JW. 2007 - A multi-gene phylogeny of Clavicipitaceae (Ascomycota, Fungi): identification of localized incongruence using a combinational bootstrap approach. Molecular Phylogenetics and Evolution 44, 1204-1223.

Tibpromma S, Hyde KD, McKenzie EH, Bhat DJ et al. 2018 - Fungal diversity notes 840-928: micro-fungi associated with Pandanaceae. Fungal Diversity 93, 1-160.

Vilgalys R, Hester M. 1990 - Rapid genetic identification and mapping of enzymatically amplified ribosomal DNA from several Cryptococcus species. Journal of Bacteriology 172, 4238-4246.

White T, Bruns T, Lee S, Taylor J. 1990 - Amplification and direct sequencing of fungal ribosomal RNA genes for phylogenetics. In: Innis M, Gelfand D, Shinsky J, White T. (Eds.) PCR protocols: a guide to methods and applications. Academic Press, New York 315-322.

Wijayawardene NN, Hyde KD, Lumbsch HT, Liu JK et al. 2018 - Outline of Ascomycota: 2017. Fungal Diversity 88, 167-263.

Zhang JF, Liu JK, Hyde KD, Yang W et al. 2017 - Fungi from Asian Karst formations II. Two new species of Occultibambusa (Occultibambusaceae, Dothideomycetes) from Karst landforms of China, Mycosphere 8, 550-559.

Zhang Y, Wang HK, Fournier J, Crous PW et al. 2009 - Towards a phylogenetic clarification of Lophiostoma/ Massarina and morphologically similar genera in the Pleosporales. Fungal Diversity 38, 225-251.

Zhaxybayeva O, Gogarten JP. 2002 - Bootstrap, Bayesian probability and maximum likelihood mapping: exploring new tools for comparative genome analyses. BMC genomics 3, 1-4. 